\title{
Traversing Birth. Continuity and Contingency in Research on Development in Nineteenth-Century Life and Human Sciences
}

\section{Preprint}

Published in: History and Philosophy of the Life Sciences, 2015, 37, 1, S. 50-67.

Caroline Arni

Universität Basel

Hirschgässlein 21, 4051 Basel, Switzerland

+41612959673

caroline.arni@unibas.ch

\begin{abstract}
In the history of life sciences, it has often been argued that the individual organism emerged, around 1800, as a four-dimensional entity - a temporalized entity. Against this backdrop, the article asks how research on development contributed to structuring the time of the organism in terms of a historical process, that is, by understanding a given phenomenon as brought forth by what preceded it and as establishing conditions for what will follow, thus relating the past, the present and the future in a specific way. To shed light on this conceptualization, we must take into account not only embryological research on morphogenesis but also physiological research on the genesis of vital functions and the causation of congenital anomalies. Three layers of structuring time in such research may be discerned: the making of a trans-natal continuity of the developing organism; a conceptualization of birth as a threshold of past and future that paradigmatically reveals the historical understanding of such developmental continuity; and an approach to intergenerational transmission that confronts developmental continuity with historical contingency. My contribution focuses on the work of William T. Preyer and Charles Féré but, in a genealogical vein, situates their work in the larger context of nineteenth-century research on development.
\end{abstract}

Keywords: development, embryo, prenatal, birth, embryology, fetal physiology

Short title: Traversing birth 


\section{Traversing Birth. Continuity and Contingency in Research on Development in Nineteenth-Century Life and Human Sciences}

In 1880, ending a talk on "psychogenesis", the physiologist and psychologist William Thierry Preyer gave himself over to a kind of epistemological vertigo as he mused on the object of his research:

To be sure, when I look back over my work, those daily attempts, for years, to fix processes of development, it seems to me as if I stood at the banks of a shining stream that constantly gains in breadth, flows at an accelerating pace and into whose clear waters I plunge my searching gaze without gaining ground, even when no wanton wave curls its surface. Amazed and mute we stand before the eternal enigma of becoming [vor dem ewigen Räthsel des Werdens]. [...] We marvel at our development and do not understand it. (Preyer 1880, 237) ${ }^{\mathbf{1}}$

When Preyer described his labouring over the "enigma of becoming", he stood at the intersection of two disciplines concerned with human development: embryology and child psychology. A gifted synthesizer of scattered research traditions and wider research trends in the human and the life sciences, in both fields he staked claims to broaden research approaches: while embryology, he argued, must ask not only after the "genesis" of form but also after the "genesis" of vital functions, psychology could not begin with the born child but must also take into account the unborn one. By implication, he had two disciplines converge in a perspective on human development that would assert not only a continuity between physiological and psychological processes, but also a continuity between the unborn organism and the born human subject - or, more precisely, that would assume the latter on the basis of

\footnotetext{
${ }^{1}$ Unless otherwise indicated, all translations in this article are mine.
} 
the former. Better than in any declamatory statement, this claim is encapsulated in the chronology of Preyer's books on the topic. The 1882 publication of his highly influential Die Seele des Kindes (first translated into English in 1888-9 as The Mind of the Child), which laid out the "mental development of the human being in the first years of life" (Preyer 1882/1905), was followed just one year later by the appearance of Specielle Physiologie des Embryo, which presented a host of research on embryo-foetal circulation, oxygen supply, nutrition, metabolism, secretion, motility, sensibility, growth, and so on. Although in this arrangement the unborn and the born were treated separately, the separation was merely technical, designed, as Preyer writes, to "make it easier both for the investigator to do his work and for the reader to follow the exposition of its results" (Preyer 1882/1905, ix). It did not imply an epistemological division, since the research task remained the same in both books: to study the child, "both before birth and in the period immediately following, from the physiological point of view, with the object of arriving at an explanation of the origin of the separate vital processes" (Preyer 1882/1905, ix).

Preyer's endeavour offers a salient entry point for this article, which introduces additional protagonists and moves further back in time in order to inquire into temporal concepts in research on human development in both the human and the life sciences. Preyer is particularly interesting because his work and its reception reveal the convergence of two research fields equally relevant to this article: firstly, a research tradition stemming from the early nineteenth-century engagement with development from a physiological perspective, and, secondly, a heterogeneous research field inquiring into the circumstances of the becoming of the human organism before birth in terms of its impact on the born human subject. I will discuss the first of these approaches, using Owsei Temkin's terms (1950), as “historical physiology", and the second as the "epistemic space" (Rheinberger and Müller-Wille 2007) that, from the late nineteenth century on, took shape under the heading of the "prenatal" or the 
"antenatal". While Preyer systematized a vast amount of the practical research that had been carried out over the nineteenth century in the first field, his own work served as a reference point for subsequent authors engaged with the second.

It has often been observed that the living emerged, in the eighteenth century, as a fourdimensional entity, "indissolubly joined not only to the space that surrounds it, but also to the time that has moulded its present structure" (Jacob 1973, 130). "Time was indeed the measure of all things", writes William Coleman (1977, 10), and Michel Foucault argues that from the nineteenth century on, "History ... defines the birthplace of the empirical, that from which, prior to all established chronology, it derives its own being" and which brought forth the human as an object of scientific disciplines (Foucault 1974, 219 and 263-279; see also Lepenies 1976). This historicity of the living emerged in a twofold form: as phylogenetic "evolution" and as ontogenetic "development". The living being was understood as the product of both the history of its ancestors and the transformations that brought about its individual organism (Jacob 1973, 130).

Situating my contribution within this broad context, a heuristic specification is in order. If in some of the passages quoted above - and in my assemblage of them - "temporality" and "historicity" are lumped together, it is important to point out that they are not synonymous in describing the "four-dimensional" conceptualization of the living. When the passing of time came to be understood as "history", a particular interpretation of temporality was at work: a view of a given phenomenon as having been brought forth by what preceded it and, in turn, establishing conditions for what would follow (Temkin 1950, 234; Koselleck 1985). ${ }^{2}$ Thus, to conceive of organisms and species as "historical" implied more - or, according to Foucault,

\footnotetext{
${ }^{2}$ Whether a temporal process grasped in terms of a historical process is conceived of as teleological or contingent was, in the nineteenth century, a matter of interpretation, especially when the notion of evolution shifted between a "developmental" and a "genealogical" approach (Bowler 1996).
} 
even something else - than placing them in the flux of time: it endowed the time of the living with an explanatory principle, in that its features were seen as derived from a specific nexus between the past, the present and the future. François Hartog has coined the term "regimes of historicity" (Hartog 2003) to draw attention to the fact that there are different ways of relating past, present and future in terms of "the historical". To carefully describe these different ways and, more generally, to understand temporality-as-historicity not as self-evident but as, precisely, the thing in need of interpretation is to enable a more far-reaching examination of the temporality of the living. Asking how a specific regime of historicity operated in sciences of the developing organism, I will investigate the concerns at stake in conceptualizing relations between the past, the present and the future. Continuity and contingency, that is, the intervention of non-determined events in a continuous process, I will argue, were such concerns.

The research problem that brought forth "development" in early nineteenth-century embryology was the question of how to think of an organism that presents an organized structure while also undergoing permanent change (Wellmann 2010, 115-116). The concept of rhythm, as an interplay of repetition, regularity and variation, offered an answer to this question (Wellmann 2010). ${ }^{3}$ But while rhythmic development could account for the continuity of an ever-changing organism with regard to morphogenesis, the question arose afresh, this time from the perspective of a physiological and psychogenetic approach and moving beyond embryology, with regard to the change that an organism underwent through the single and momentous event of birth. In this context, I argue, the present and the future of the organism were related to each other in the mode of a historical connection that on the one hand accounted for the continuity of the developing organism, yet on the other raised the question of contingency. This nexus, unfolding in research on development through the nineteenth

\footnotetext{
3 On the making of "development" in a later phase of embryology, see Hopwood 2000.
} 
century, comes to light when such research is investigated as a comprehensive, markedly transdisciplinary field that comprised physiological, psychological and pathological approaches.

I develop this argument in three sections. In the first, I ask how early nineteenth-century physiology brought forth a developing organism characterized by trans-natal continuity. Examining subsequent psychophysiological research on the newborn that drew on this concept, in the second section I show how this organism was conceived of as producing continuity by converting past into future. The third section turns to prenatal pathology as it was researched in the late nineteenth century, to shed light on how such continuity was coupled with the question of contingent events that interfered with development. In conclusion, I suggest that a concern to account for continuity and contingency constitutes a common matrix that brought forth the historicity of the living with regard to phylogenesis and ontogenesis alike.

\section{Beyond embryogenesis: The making of trans-natal continuity}

When William T. Preyer published his book on the "special physiology of the embryo" in 1883, he insisted that his research program was both an integral part of and a challenge to embryological research, calling for an end to embryology's indifference towards physiology and for attention to what he designated "physiological embryology", "biochemical and physiological embryognosis" or "functional embryology" (Preyer 1883, 1-3). Despite terminological similarities, his claims departed from embryology's then current turn towards "physico-chemical techniques and explanatory principles" as stipulated by the embryologist Wilhem His in 1874 (Coleman 1977, 54). His's call for a "physiological morphology" was eventually answered when embryology turned from a descriptive and comparative science into an experimental science under the heading of "Entwicklungsmechanik" in the 1880s 
(Coleman 1977, 53-54; Maienschein 2003, 13-88; Mocek 1998; Hopwood 2009). However, although the discipline had now shifted from its previous concern with describing embryonic forms to studying their biochemical causation, it continued to focus on morphogenesis and thus the early stages of development. For Preyer, in contrast, taking account of physiology meant moving the focus from the emergence of embryonic form to the vital functions of the formed organism. This surpassed the temporal scope of the embryological discipline: for Preyer, physiological embryology begins where morphological embryology ends, once embryonic forms are attained, and it ends not with birth but with the first intake of food "outside the egg" as the final event of the physiological adaptation that was triggered by birth (Preyer 1883, 17).

Preyer may not have been in tune with the kind of physiological turn that contemporary embryology was approaching. But he addressed physiology as well as embryology, calling on physiology to take a "genetic" approach by concerning itself with the foetal organism. With regard to this claim, Preyer, who presented himself as the founder of a new discipline and has been received as such both by his contemporaries and by historians of science (Fischer 1999, 393), should probably be regarded instead as a "systematizer" of a continuous stream of research being carried out throughout the nineteenth century. The Entwicklungsgeschichte of vital functions for which he called can be traced back to early nineteenth-century engagements with development from a physiological perspective. Though closely associated with the establishment of epigenetic principles in embryological research and increasingly focusing practical work on "developmental morphology" (Lenoir 1982), such engagement initially reached beyond embryogenesis as just one, albeit a fundamental, subject of a more comprehensive "historical physiology" (Temkin 1950, 234-236). Ignaz Döllinger, for example, a teacher and collaborator of Pander and von Baer and an important initiator of physiological work, thought of development as an ongoing, life-long process that extended 
from conception to death and consisted in a constant renewal of conception (Döllinger 1842, $3-4){ }^{4}$

Döllinger is interesting because he gives a precise definition of what "historical" meant and why it had explanatory value:

In this course of life and passing of existence the single phenomenon itself cannot have any significance for itself; for everything that at a certain time appears as part of the process has its peculiarity only by what preceded it and thus prepared it and gave rise to it. And its value consists merely in its contribution to the establishment of a coming stage of development. Thus, the knowledge of individual human existence cannot truly be other than historical. (Döllinger 1842, 3-4) ${ }^{5}$

Since here the individual organism is subject to permanent development, physiology is history, and any explanation of the individual organism over the course of life has to be historical. It attests to the coherence of his approach that Döllinger addressed research on foetal oxygen supply by refuting the notion of "foetal respiration" as anachronistic - that is, as methodologically flawed historical thinking:

In a study whose principles are to be founded solely on a strictly historical course, the question of how the foetus breathes can actually not be raised, since this is only the detection of an early surrogate for a phenomenon that occurs in the later periods of development, flying in the face of every sense of history [allem historischen Geiste zuwider]. (Döllinger 1842, 379)

\footnotetext{
${ }^{4}$ Döllinger here sets out what Claude Bernard later called "silent embryogenesis", that is, the life-long reconstruction of the individual organism (Prochiantz 2012, 41-56).

${ }^{5}$ Temkin's translation (Temkin 1950, 234).
} 
Preyer does not mention Döllinger, although he would have found his own claim laid out in Döllinger's fragmentary and incomplete work, for instance in his review of the development of blood circulation by progressing from the embryonic through the foetal to the born state. He does reference, however, a prizewinning 1824 article by the young Johannes Müller that dealt with "the physiology of the foetus" firstly by describing the form and functional features of the fertilized egg and its envelopes, and secondly by presenting numerous vivisectional experiments on foetal oxygen supply in rabbits and sheep (Müller 1824). Müller like Preyer took care to emphasize the distinctly physiological approach of his work by crediting Meckel's and Serres's work on “morphogenesis" (Bildungsgeschichte), while simultaneously arguing that it could be ignored for his own work since it was "more closely affiliated with morphology than physiology" (Müller 1824, 423). ${ }^{6}$

Like Döllinger's, Müller's physiological approach to the unborn called on physiology to apply a developmental perspective on vital functions beyond both embryogenesis and birth. The chapter "On Development" in the second volume of his 1840 handbook on physiology discussed the egg, the embryo, the foetus, birth and "developments after birth". Admittedly, he considered the last point to be of minor relevance: "Developments continue after birth and through a large part of life without, however, being as fundamental as in foetal life" (Müller 1840, 764). For Müller and other physiologists - especially Karl Friedrich Burdach, to whom Müller referred his readers for more information - development after birth was not the constant fundamental transformation that Döllinger postulated, but the succession of different “Lebensalter” (Müller 1840, 765-766). Yet common to both Döllinger's more radical and

\footnotetext{
${ }^{6}$ Such remarks can be situated within the context of physiology's struggle for a disciplinary autonomy from anatomy, which accompanied the presentation of the functional approach as an integrative perspective on the study of the organism (Canguilhem 1970; Prochiantz 1990, 55-56). For Müller's efforts in this context, see Hagner 1992.
} 
Müller's more moderate approach was the idea of a trans-natal continuity of the developing organism. While in Müller's account birth leads from fundamental to more peripheral developmental phenomena, in Döllinger's it moves the developing organism from one life period to the next by changing its "externality" (Aeusserlichkeit) without altering its developmental impulse. There is the period before birth, when the organism is part of the maternal body's externality and strives for a "free earthly existence of its own", and the period after birth when the organism is part of the externality of the "earth" while fending off the earth's invasive forces in an ongoing effort to achieve and maintain "autonomy" (Selbständigkeit) (Döllinger 1842, 278-379). Sharing this concept of birth as a passageway that alters the organism's relationship to what is external to it while preserving organismal continuity, Müller writes that through birth, the child becomes an "autonomous" (selbständiger) body "foreign to the uterus" (Müller 1840, 760).

These descriptions not only shed light on how the period before birth was inserted into a continuous course of life; they also attest to a distinctly physiological notion of gestation and the unborn that began to emerge in the eighteenth century and was consolidated throughout the nineteenth century. When William Hunter proved, in his Anatomy of the Human Gravid Uterus (1774), that the unborn did not partake in the maternal blood circulation, long-held doubts as to whether the pregnant woman and the unborn constituted an organic unity gained new momentum. ${ }^{7}$ Hunter's demonstration was followed by a large amount of anatomical and experimental research on the placenta as an organ that differentiates the unborn from the maternal body while simultaneously connecting them through the provision of nutrition and oxygen. Such research on gestation coincided with the ascendance of the notion of the "organism" as a "generic name of individuals" in natural philosophy and a "structure-function complex" in research on the living (Cheung 2010, 156, 178). In the first decades of the

\footnotetext{
${ }^{7}$ Uncertainty continued throughout the first half of the nineteenth century (de Witt 1958).
} 
nineteenth century, a notion of the organism as a "living, individualized entity" (Cheung $2010,179)$ that was always also bound to an environment or "milieu" (Jacob 1973, 155) became established in various research fields.

In this context, the unborn, no longer understandable as an organic part of the maternal body, became instead a "biological object" of its own (Duden 2002, 11), that is, an individual organism residing in the maternal organism as its specific milieu. What was once an organic unity was now regarded as a relation of "communication", "correlation" or "exchange" between two individual organisms. In this vein, Burdach's handbook of physiology shows both the "mother" and the "embryo" as "individuals aspiring to a peculiar existence or trying to maintain such an existence, but both also constitute a community, they interact and are dependent on one another" (Burdach 1828/1837, 105-106). ${ }^{8}$ Johannes Müller describes the "connection between mother and child" in terms of a "juxtaposition as intimate as possible of two actually completely self-contained beings, which attract each other on their respective surfaces, one of them giving the nutrition and warmth of which the other takes possession" (Müller 1840, 574). Not surprisingly, this concept of gestation is frequently anchored in the observation that the embryo "does not receive its blood but generates it itself" through active “appropriation” (Aneignung) (Burdach 1828/1837, 799).

Hence there is, contrary to Temkin's interpretation $(1950,236)$, nothing "strange" about the fact that Döllinger develops his argument on the two phases in the life of the human individual - before and after birth - in a chapter on the cardiovascular system, describing them as "two main epochs in the genesis of the circulatory system" (Döllinger 1842, 279).

\footnotetext{
8 While always postulating it, physiologists were less concerned with the mother's "dependency" on the embryo. This can be explained by the fact that the developing organism of the unborn was at the centre of their respective thinking. However, the issue merits more research, which probably would have to take into account how obstetricians and gynaecologists received physiological knowledge production on gestation.
} 
When interpreted from the perspective of the connection between the emergence of historical physiology and a concept of gestation centred upon the becoming of an individual organism, this textual organization makes perfect sense: the time periods before and after birth can be presented as two phases with regard to the continuous individual organism that passes from one phase (where its blood circulation depends on the maternal organism) to the other (where it has achieved autonomy from the maternal organism). Development in utero was thus understood as a "gradual achieving of self-containment" (Burdach 1828/1837, 3).

However, the assumption that the unborn was an individual organism dependent on "the organic influence of maternal life", and thus "characterized as mainly a product", both established and dissolved its distinction from the born, since "the individual organism never ceases to be a product" of its external milieu (Burdach 1828/1837, 3). This concept of transnatal continuity is exactly what can be found in Preyer's 1883 book. He describes birth as a passage from water to air, from darkness to light, from silence to noise: as a continuous organism changing its milieu (Preyer 1883,6). That passage is certainly relevant, since it provokes profound functional adaptations; but it is just one event in a developmental continuum. ${ }^{9}$ The researcher's gaze has to cross birth in both directions, and most significantly so when it comes to the issue of psychogenesis. Turning now to this field, I will show how trans-natal continuity was made not only in concepts but also through research practice, where it became apparent as a specific way of relating the past and the future.

\footnotetext{
${ }^{9}$ In the same vein, philosophy of life science today considers "birth and hatching as arbitrary time markers for the beginning of the organism", since "life in the embryological environment and life after birth or hatching are more continuous than it might appear" (Nuño de la Rosa 2010, 299). It is not the concept of trans-natal continuity itself, in the sense of ontologically conflating the born and the unborn, that is novel to modern life sciences - such continuity was already conceived of in ancient and theological embryologies that assumed "ensoulment" at a specific moment before birth. However, within the context of modern life sciences the question has been posed in a novel way, as one of organismal continuity that cannot deliver a definite answer to the question of when the unborn is ontologically equivalent to the born. The political and ethical implications of this problem are well-known.
} 


\section{The developing organism at birth: Converting past into future}

In 1893, the French philosopher and educationist Gabriel Compayré noted "that there is no more interesting moment to study in the life of the child than that in which he comes into the world" (Compayré 1893/1900, 28). Including a chapter on the newborn in his study of the "intellectual and moral development of the child", Compayré took up Preyer's call to conceptually unite research on the child before and after birth. Preyer's work on the embryo and psychogenesis is frequently cited in Compayré's study, and he appears on the scene on the second page as a commendable example of those

diligent and eager observers [...] who lose no time, who do not wait even till the child has had five minutes of existence before taking him to the window to see what effect the light of day exercises upon his eyes; who do still better than this, even, since they anticipate the complete birth, and profit by the fact that the child's head appears first, to experiment upon the force of his instinct of suction by putting the end of his finger in his mouth. (Compayré 1893/1900, 29) ${ }^{10}$

Compayré's work is just one example of literature in the nascent developmental psychology of the period that took the newborn as a starting point and presented birth as a territory for practical research. For this field, Preyer served as a crucial reference. In an extraordinarily detailed account based on observations and experiments, in the first section of his Seele des Kindes of 1882 Preyer described the "development of the senses" in the newborn and the infant, examining vision, audition, touch, taste, smell and feelings of well-being, dislike, hunger, saturation, fatigue, anger and surprise (Preyer 1882/1905). Preyer's interest in the newborn drew on historical physiology and the concept of the trans-natal continuity of the

\footnotetext{
${ }^{10}$ Preyer's books appeared in French translation in 1887 . As early as 1881 , his article on psychogenesis was published in French in the Revue philosophique de la France et de l'étranger, a journal edited by Théodule Ribot as an organ for clinical psychology and experimental psychophysiology (see, e.g., Mucchielli 1998).
} 
developing organism I have described above. The same impulse to investigate the newborn had been pursued by Adolf Kussmaul, who was one of the many physician-scientists influenced by Johannes Müller (Schafer 2009, 27-28). In 1859, Kussmaul published a short and subsequently much-cited book entitled Untersuchungen über das Seelenleben des neugeborenen Menschen as a contribution to the study of the "evolution of the human soul" (Entwicklungsgeschichte der menschlichen Seele) (Kussmaul 1859, 6). In its first section, he reviewed statements on the sensual capacities of the unborn and the newborn ranging from antiquity to the present. In the second, he presented his own research, which consisted in observing newborns and testing their reactions to sensory stimuli, for example their facial reaction to tasting bitter or sweet substances.

As a research object, the newborn served, on the one hand, as an ersatz object in human foetal physiology because it could substitute for vivisection. Preyer thus presents research on newborns as one way to cope with the impossibility of "observing the [human] foetus in its natural environment and investigating its vital expressions while it is still developing in the uterus" (Preyer 1883, 6-7). If only the physiologist could have access to what he calls "justborn children" (ebengeborene Kinder) (Preyer 1883, 5), he would get a glimpse of the unborn human organism otherwise hidden away in the female body. On the other hand, the newborn was a research object in its own right when examined from a psychogenetic perspective - and that perspective was inscribed from the outset into the physiological engagement with the developing organism.

When physiologists, psychologists and physicians put their finger in the mouth of a not yet fully born child, when they made the newborn taste quinine and sugar, when they exposed its eyes to a moving candle and brought chinking bells to its ears, tickled its tongue with a glass rod and made it smell acetic acid and ammoniac, they did so in the context of a physiology of 
the senses and its postulate of a psychophysiological continuum. The idea that psychological phenomena were rooted in physiological processes - and that physiology would thus yield psychological knowledge - was formulated "most forcefully and precisely" by Johannes Müller in the early nineteenth century (Hagner 2008, 239; Hagner and Wahrig-Schmidt 1992). Bypassing the question of how the psyche was localized in the brain, and searching for a viable experimental approach to the body-mind interaction, Müller saw the physiology of the senses as a way of conflating physiological and psychological questions. His endeavours were imbued with a developmental perspective, since it was then widely assumed that a human organism's potential culminated in psychic phenomena (Hagner 2008, 238-239).

This physiology of the senses subsequently informed both Kussmaul's and Preyer's work. Preyer states that "the foundation of all mental development is the activity of the senses": "We can not conceive of anything of the nature of mental genesis as taking place without that activity" (Preyer 1882/1905, 1). From this perspective, sensation is the organismal feature that generates the trans-natal continuity of the organism: "Everything goes to show a continuity in the capacity of sensation" (Preyer 1882/1905, xiv). ${ }^{11}$ Accordingly, he concluded his book on foetal physiology with a chapter on "embryonic sensibility", followed only by a short chapter on embryonic growth, while his book on the child starts with a chapter on the "development of senses and feelings" in the newborn and the infant, followed by chapters on the development of volition, reason and language. Embryonic sensibility was thus inserted into a continuous process of successive stages in the child's development, and a focus on the senses is what makes research on the unborn overlap with research on the born. This approach brought forth the newborn as a research object in its own right.

\footnotetext{
${ }^{11}$ Preyer's argument is twofold: he assumes on the one hand that sensual capacity develops through external stimuli and the ensuing activity effective before birth; on the other that a phylogenetic heritage is present from the beginning in every new organism. He brings the two points together by arguing that psychic capacities are given but have to be "awakened" (Ottavi 2001, 131; see also Canguilhem et al. 1962/2003, 91-92; Eckardt 1989).
} 
However, its epistemological significance went beyond that of supplying knowledge about the organism at the moment of birth. What became manifest in research on the newborn was development as a process that extends over time in a way that refers the researcher simultaneously to what came before and what will come next in order to assess the meaning of the given present - which itself is understood as a product of the past and a condition of the future. In Preyer's book this logic can be seen in the textual organization, but in Kussmaul's writing, as in that of many other authors, it manifests on a linguistic level. There, it is the notion, recurrent in the language of "historical time", of the "already" (Koselleck 1985) that defines the unborn by the born and vice versa: "When man, coming from the mother's womb, enters this life, he already possesses a well equipped sensorium [...]. Yet the newborn possesses not only excellent instruments [...], but already in the maternal body has begun to make use of some of them and, despite the adverse conditions of that place, has gathered some experience and capacities" (Kussmaul 1859, 35; original emphasis). ${ }^{12}$

Within this research context, birth is demoted to being a mere event in an organismal continuum, based on the assumption of psychophysiological continuity, yet also valorized as a privileged means of gaining knowledge on development. This is no contradiction. If birth serves as a means to research the features of the (past) unborn with regard to the (future) born, it yields an "epistemic thing" (to use Hans-Jörg Rheinberger's term) that is defined not by the momentary event that produces it, but by this moment's relationship to the past and the future. The newborn is no longer foetus and not yet child, but also still foetus and already child; it refers to what it was and what it will be, and thus conflates a past made for the future with a future conditioned by the past. The continuously developing organism is not one that moves

\footnotetext{
12 To be sure, consensus on how to assess sensual activity before birth from a psychogenetic point of view was far from having been achieved, and controversies continued long after the nineteenth century.
} 
through a continuous stream of time, but one that brings forth continuity by incessantly converting past into future. Conceptualized thus, the developing organism is divested of a present that can, in research, be construed only through artefactual objectivation in an experimental setting. Hence the obsession with the passing of time in research on the newborn. When Preyer laments the "merely external mischief" of the distance between the physiological laboratory and the delivery ward, which impedes "many attempts to experiment methodologically with newborns" (Preyer 1883,5 ), the problem is actually anything but external: to merge the two settings spatially would mean nothing less than to temporally synchronize being born and doing research, in a futile attempt to arrest the time of development - precisely the fantasy at work when physiologists rush into delivery wards and put their fingers in the mouth of the child during labour.

\section{Gestational accidents: Contingency in development}

I have argued that the developing organism was, in nineteenth-century physiology, conceived of as bridging the unborn and the born by continuously converting past into future. However, birth still being (from a physiological perspective) a specific transformational event, such continuity raised the question of how what happens to the organism before birth impacts on its future after birth. The long-standing phenomenon of congenital anomalies and disease thus came to be understood in these terms when it began to be examined within the context of the physiological conception of gestation described above. A crucial author in this field was the French alienist Charles Féré, who undertook a series of experiments on development in the last decades of the nineteenth century and was subsequently often cited alongside Preyer.

Féré too was interested in the foetus from a psychophysiological perspective. He turned to the unborn when researching sensory-motor physiology and seeking motoric equivalents to 
"psychic operations" (Féré 1886, 261). ${ }^{13}$ Foetal movement, he argued, can be understood as a mediated version of the sensorial excitation that effects muscular contraction: the pregnant woman's sensations lead to contractions of the uterus that are felt by the foetus, which, in turn, begins to move (Féré 1886, 261). Although Féré here entered a long-standing controversy about the nature of foetal movement, his main concern was not to prove foetal sensation. When he argued, on the basis of experiments and reports by women, that the foetus "reacts, in its uterine cave, [...] to any sensation, whether perceived or not, and to any of its mother's mental representations", he was concerned first and foremost with the link between the maternal and the foetal organism (Féré 1886, 256-258). And this concern was framed not by an interest in psychogenesis but in pathogenesis. Thus, in a remarkable argumentative leap, Féré's article on "foetal psychology" concluded with the hypothesis that repeated and intense sensorial or emotional excitations in the pregnant woman might irritate the nutritional bond and the foetal nervous system, thus producing congenital pathologies (Féré 1886, 260).

This hypothesis could not be evaluated within the confines of sensory-motor physiology. In the following years, Féré therefore replaced pregnant women with chicken eggs and turned to “experimental teratogeny", continuing the work of Étienne and Isidore Geoffroy Saint-Hilaire and, especially, Camille Dareste (Oppenheimer 1968; Fischer 1986). Following their example, Féré shook, varnished, and perforated eggs, varied their temperatures and positions, immersed them in vapours of musk, phosphor and ammoniac. In addition, aiming to put teratogeny in the service of "general pathology", he varied experimental intervention by injecting "toxic substances" (alcohol, cocaine, etc.) and "microbic toxins" (syphilitic substance, etc.) - that is, by introducing elements that correlated with toxic and infectious phenomena in human medicine. Summarizing his results, Féré argued that nutrition was the

\footnotetext{
${ }^{13}$ The article appeared in the same review as the French version of Preyer's paper on psychogenesis (see footnote 11).
} 
medium through which substances that caused disease in pregnant women exerted a pathogenetic effect in the unborn. This result was indeed of general pathological relevance, since it could also be demonstrated that the same substances which produced morphological anomalies in an early developmental state caused functional anomalies such as infertility, morbidity or debility in a later developmental phase (Féré 1899).

Joining research on teratogenesis with research on pathogenesis, Féré established a unifying category. Malformation and congenital morbidity were two manifestations of the same phenomenon: "Like monstrosity," Féré argued, "morbid predisposition is the result of troubled evolution" (Féré 1894, 446). They differed not in being different effects of different causes but in having the same causes but different effects according to the period of gestation when they intervened, gestation itself being structured by developmental stages. This insight was immediately taken up and terminologically codified by the Scottish gynaecologist John W. Ballantyne. He envisioned the founding of a new discipline called "antenatal pathology". Its novelty, Ballantyne argued, consisted not in its choice of subjects, that is, "monstrosities", "foetal diseases" and "morbid predispositions", but in integrating them into a single research perspective concerned with "all the morbid processes which act upon the organism before birth" (Ballantyne 1902, 1-2; Al-Gailani 2010). ${ }^{14}$ This category of the "prenatal" restates the double feature of birth described above: while birth on the one hand marks an epistemologically relevant discontinuity, in that it distinguishes what happens before in terms of its impact on what comes after, it is also just one event among others in the continuous aetiology of the organism.

\footnotetext{
${ }^{14}$ Ballantyne did not invent the terms "antenatal" or "prenatal" (or, in German, vorgeburtlich) that were used here and there by other authors, among them Preyer, early in the nineteenth century. However, he was the one to give the term a programmatic momentum at a time when authors were still vacillating between a spatial and a temporal conceptualization, using "intrauterine" and "antenatal" in parallel. An example is Ballantyne's French counterpart Adolphe Pinard (Herschkorn-Barnu 1996). On "the prenatal”, see also Arni in press and Arni 2012.
} 
As for its subjects, Féré's research did indeed continue traditional medical interests in the origin of congenital disease, morbidity and malformation. ${ }^{15}$ What enabled him to integrate all these, however, was the physiological conception of gestation as the time period in which the organism was characterized by residing in a specific milieu in the mode of dependency on the maternal organism. "Morbid processes" acting "before birth" could thus be thought of as pathogenic "influence". The quest for such "influence" informed and integrated Féré's bifurcated approach to research on the unborn, motivated as it was by the question of whether the trauma experienced by besieged Parisian women during the Franco-Prussian War in 1870/71 and the Paris Commune uprising in spring 1871 might be the cause of the disproportionate incidence of behavioural anomalies in children conceived at this time (Legrand du Saulle 1884; Féré 1884). Tellingly, Féré posed this question in terms of "psychic influence".

However, while in the physiological conceptualization of gestation upon which Féré draws any organism, born or unborn, is subject to a milieu, in the case of the unborn this milieu is itself an organism. More precisely: its milieu is the organism which brings about the unborn through a procreative process - one now no longer understood as a single act of parents generating a new human, but rather as the continuous reproduction of the species, linking generations as its specific actualizations (Rheinberger and Müller-Wille 2009, 31-63; Parnes 2007; Parnes, Vedder and Willer 2008). In the case of gestation, then, environmental influence is a medium of intergenerational transmission: the experience and life conduct of a pregnant woman translates into the features of the prospective child by conditioning and, in some cases, detrimentally interfering with its development.

\footnotetext{
${ }^{15}$ It also dovetailed with the medicalization of the foetus that had taken off in the first part of the century (Herschkorn-Barnu 2002) and with long-standing theories of manipulative interventions aiming for the "perfection" of the prospective child (Fischer 1991; Carol 1995). Féré showed explicit interest in how nutrition might be used to create conditions favourable for development (Féré 1894, 452).
} 
This implication explains Féré's interest in developmental pathologies, since he was not only an alienist engaged in psychophysiological research but also a contributor to the Société de biologie who was deeply interested in the vexed question of heredity and "degeneration". Hence his concern, when drawing conclusions from his research on chicken eggs, to distinguish prenatal pathology - which he called "morbid heredity" caused by "accidents of conception or gestation" (Féré 1886, 259) - from "heredity": "Exposing the influence of most varied toxic substances in the milieu where the embryo develops, [the experiments] point, in a general way, to the degenerative quality of troubled parental nutrition; but they do not directly touch upon the question of heredity" (Féré 1899, 367; see also Féré 1894). In arguing thus, Féré continued a long-standing French interest in the causation of congenital anomalies by way of "heredo-intoxication"; that is, the infliction of a physico-chemical injury on the germ and the developing organism by its milieu (Mendelsohn 2001). This "accidental” origin of pathology was distinguished from "true heredity" as the regular reproduction of parental pathological traits in the offspring (Mendelsohn 2001, 40). ${ }^{16}$ However, they were treated together since they both explained the pathologies of the child as related, in one way or the other, to mechanisms operative in the procreative act, in other words as revealing various mechanisms of transmission. Even when, at the beginning of the twentieth century, the concept of the gene arose and the notion of heredity was narrowed down to the transfer of an assumed stable hereditarian substance, these "dual approaches to transmission" continued (Gaudillière and Löwy 2001, 7-9). Significantly, later authors referred to Féré's work under the heading of the "prenatal" (e.g. Vignes 1924) as well as by continuing the notion of "morbid heredity" (e.g. Apert 1919).

\footnotetext{
${ }^{16}$ The terminological overlap of "true heredity" and "morbid heredity" reveals that, in nineteenth-century France, interest in heredity arose in a medical context (Lopéz-Beltrán 2004, 2007) which had to account for both phenomena. Hereditarian medicine thus was "as much a medicine of reproduction and development as of the 'true heredity' that most of its practitioners were able to distinguish" (Mendelsohn 2001, 40).
} 
To conceive of development as a continuous process, brought about by an organism that constantly converts its past into its future, inevitably raised the question of contingency, a question inherent to any historical process not regarded as predetermined. Prenatal pathology can be understood as a way of dealing with the disconcerting issue of contingency in the developmental process. Because contingent events in the sense of gestational "accidents" were, furthermore, addressed as an interference with transmission, such contingency concerned not only organismal but also intergenerational continuity. Contingency happened when two generational times coincided in the developing organism through its physiological relationship to the maternal "milieu": during gestation, the present of the mother becomes the future of the prospective child if accidental events and circumstances belonging to the biographical time of the mother (her diseases, nutritional deficiencies, traumatic experiences, etc.) deform the future, that is, the biographical time of the prospective child. As a result, Féré could present the detrimental influence of a mother's organism as an instance of "degeneration". 17

\section{Conclusion}

Understanding the living organism as the product of the time that brought it about implied making connections between the past, the present and the future that were not self-evidently given. This article has explored the making of continuity and contingency in the developing organism across birth. I have argued that, in early nineteenth-century physiological approaches to gestation and development, the unborn was conceived of as an individual organism whose developmental trajectory traversed birth, thus instituting continuity between

\footnotetext{
${ }^{17}$ It is important to note that Féré adhered to a concept of "degeneration" as formulated by Bénédicte Augustin Morel in 1859. Morel had argued within the context of milieu theories and thus stressed accidental and environmental causes; the stable transmission of specific anomalies was only one, and not the main, manifestation of "degeneration" (Mendelsohn 2001, 43-44; see also Carol 1995). On prenatal pathology and transmission, see also Arni in press.
} 
the unborn and the born. This notion informed subsequent research on psychogenesis, in which the development of psychic capacities after birth was related to their physiological conditions developed before birth. By analysing the practical problem of such research - the impossibility of capturing a specific moment where the physiological becomes the psychological - I have shown how the developing organism emerged as an organism that makes its continuity by incessantly converting past into present. Examining research on congenital pathologies attributed to the interference of accidental causes in development before birth, I have argued that this connection between the past and the future, bringing about continuity, was also conceptualized as being open to contingent events which could intervene during the course of development and produce discontinuity in the shape of anomalies.

In The Logic of Life, François Jacob specifies four elements at stake when modern life science conceptualized the temporal nature of the living with regard to phylogenesis: "origin", as all living organisms can be traced back to the emergence of life on earth; "continuity", as the living is generated from the living through the mechanism of reproduction; "instability", as variation can occur within this mechanism; and "chance", as there is no intention inherent to nature which would direct transformations over time (Jacob 1973, 130). The becoming of the individual organism has been inscribed into this history of the living in complicated ways, most notably in the debates on recapitulation (Gould 1977; Canguilhem et al. 1962/2003). Some of the authors dealt with here took part in that debate, most prominently Preyer (Eckardt 1989). Instead of examining such couplings of ontogenesis and phylogenesis, I have chosen a different angle by focusing quite strictly on the temporal concepts that informed research on the individual organism. Nevertheless, in an examination of how the past, the present and the future were interrelated in concepts of the developing organism across birth, continuity, contingency and, by implication, discontinuity have also come to the fore. 
I would thus like to suggest that it was a concern to account for mechanisms of continuity and to know about the workings of contingency that constituted a common matrix of structuring time in research on the living with regard to both phylogenesis and ontogenesis. This concern was deployed in a variety of research contexts, also including post-Revolutionary social and political theories (Parnes 2007). They came together not in a unifying concept but in "transient contact areas" (Rheinberger 2001, 197) between different fields that regarded phenomena as being brought about by historical time. When historical time as a productive temporal nexus - bringing forth phenomena - necessitated the conceptualization of concrete mechanisms of continuity, discontinuity - perceived in terms of "degeneration" with regard to the social body, "anomaly" with regard to the individual organism, or "revolution" with regard to the social and political order - loomed large as a possible outcome of the historical process. The "regime of historicity" brought about by relating the past, the present and the future to each other in the mode of continuity thus implied a notion of the past as a possible danger for the future. Hence, the spectre of discontinuity warranted action in the present such as prenatal care (Al-Gailani 2010; Herschkorn-Barnu 1996) - and thus brought forth a further way of relating times to each other: namely, when the future determined the present in the mode of "anticipation" (Adams, Murphy and Clarke 2009). That, too, may have been at stake when Preyer, almost in shock, marvelled at the "eternal enigma of becoming" (Preyer $1880,237)$.

\section{References}

Adams V., Murphy M., Clarke A., 2009, “Anticipation. Technoscience, Life, Affect, Temporality", Subjectivity, 28, no. 1: 264-265. 
Al-Gailani S., 2010, “Teratology and the Clinic. Monsters, Obstetrics and the Making of Antenatal Life in Edinburgh, c.1900”, PhD diss., University of Cambridge.

Apert E., 1919, L’hérédité morbide, Paris: Flammarion.

Arni, C., in press, "The Prenatal: Contingencies of Procreation and Transmission in the Nineteenth Century”. In: Brandt C., Müller-Wille S. (eds), Heredity Produced, Cambridge, MA: MIT Press.

Arni C., 2012, “Vom Unglück des mütterlichen 'Versehens' zur Biopolitik des 'Pränatalen'. Aspekte einer Wissensgeschichte der maternal-fötalen Beziehung”. In: Sänger E., Rödel M. (eds), Biopolitik und Geschlecht. Zur Regulierung des Lebendigen, Münster: Westfälisches Dampfboot, 44-66.

Ballantyne J.W., 1902, Manual of Antenatal Pathology and Hygiene, 1: The Foetus, Edinburgh: Green.

Bowler P.J., 1996, Life's a Splendid Drama. Evolutionary Biology and the Reconstruction of Life's Ancestry 1860-1940, Chicago: University of Chicago Press.

Burdach K.F., 1837 [1828], Die Physiologie als Erfahrungswissenschaft, 2 vols, Leipzig: Leopold Voss.

Canguilhem G., 1970, “La constitution de la physiologie comme science”. In: Canguilhem G., Études d'histoire et de philosophie des siences, Paris: J. Vrin, 226-273.

Canguilhem G., Lapassade G., Piquemal J., Ulmann J., 2003 [1962], Du développement à l'évolution au XIXe siècle, Paris: PUF.

Carol A., 1995, Histoire de l'eugénisme en France. Les médecins et la procréation XIXe-XXe siècle, Paris: Seuil.

Cheung T., 2010, “What is an 'Organism'? On the Occurrence of a New Term and Its Conceptual Transformations 1680-1850”, History and Philosophy of Life Sciences, 32: $155-194$. 
Coleman W., 1977, Biology in the Nineteenth Century: Problems of Form, Function, and Transformation, London: Cambridge University Press.

Compayré G., 1900 [1893], The Intellectual and Moral Development of the Child, translated by M.E. Wilson, New York: D. Appleton.

De Witt, F., 1958, “An Historical Study on Theories of the Placenta to 1900”, Journal of the History of Medicine, 14: 360-374.

Döllinger I., 1842 [1836], Grundzüge der Physiologie der Entwicklung des Zell-, Knochenund Blutsystems, Regensburg: Verlag von G. Joseph Manz.

Duden B., 2002, “Zwischen ‘wahrem Wissen’ und Prophetie. Konzeptionen des Ungeborenen”. In: Duden B., Schlumbohm J., Veit P. (eds), Geschichte des Ungeborenen. Zur Erfahrungs- und Wissenschaftsgeschichte der Schwangerschaft, 17.-20. Jahrhundert, Göttingen: Vandenhoeck \& Ruprecht, 11-48.

Eckardt G., 1989, “Einleitung”. In: Preyer W.T., Die Seele des Kindes. Eingeleitet und mit Materialien zur Rezeptionsgeschichte versehen von Georg Eckardt, Berlin: Springer, $11-52$

Féré C., 1884, “Les Enfants du Siège”, Progrès médical, 12/13, 245-246.

Féré C., 1886, "Sensation et mouvement. Contribution à la psychologie du foetus", Revue philosophique de la France et de l'étranger, 24: 247-264.

Féré C., 1894, “L’Hérédité morbide”, Revue des deux mondes, 64, no. 126: 437-452.

Féré C., 1899, “Tératogénie expérimentale et pathologie générale”. In: Petit A. (ed.), Cinquantenaire de la société de biologie. Volume jubilaire, publié par la société, Paris: Masson et Cie, 360-369.

Fischer J.-L., 1986, De la génèse fabuleuse à la morphogénèse des monstres = Cahiers d'Histoire et de Philosophie des Sciences, nouvelle série, 13.

Fischer J.-L., 1991, “La callipédie ou l'art d'avoir de beaux enfants”, Dix-huitième siècle, 23 : $141-158$ 
Fischer J.-L., 1999, “Embryogénése”. In: Lecourt D. (ed.), Dictionnaire d'histoire et de philosophie des sciences, Paris: PUF, 392-397.

Foucault M., 1974 [1966], The Order of Things. An Archaeology of the Human Sciences, London: Routledge.

Gaudillière J.P., Löwy I., 2001, “Introduction: Horizontal and Vertical Transmission of Disease: The Impossible Separation”. In: Gaudillière J.-P., Löwy I. (eds), Heredity and Infection. The History of Disease Transmission, London: Routledge, 1-18.

Gould S.J., 1977, Ontogeny and Phylogeny, Cambridge, MA: Harvard University Press.

Hagner M., 1992, “Sieben Briefe von Johannes Müller an Karl Ernst von Baer”, Medizinhistorisches Journal, 27: 138-155.

Hagner M., 2008, Homo cerebralis. Der Wandel vom Seelenorgan zum Gehirn, Frankfurt am Main: Suhrkamp.

Hagner M., Wahrig-Schmidt B. (eds), 1992, Johannes Müller und die Philosophie, Berlin: Akademie Verlag.

Hartog F., 2003, Régimes d'historicité. Présentisme et experiences du temps, Paris: Seuil. Herschkorn-Barnu P., 1996, “Adolphe Pinard et l'enfant à naître: l'invention de la medicine foetale", Devenir, 3: 77-87.

Herschkorn-Barnu P., 2002, "Wie der Fötus einen klinischen Status erhielt. Bedingungen und Verfahren der Produktion eines medizinischen Fachwissens, Paris 1832-1848”. In: Duden B., Schlumbohm J., Veit P. (eds), Geschichte des Ungeborenen. Zur Erfahrungs- und Wissenschaftsgeschichte der Schwangerschaft, 17.-20. Jahrhundert, Göttingen: Vandenhoeck und Ruprecht, 167-203.

Hopwood, N., 2000, "Producing Development: The Anatomy of Human Embryos and the Norms of Wilhelm His", Bulletin of the History of Medicine, 74: 29-79. 
Hopwood N., 2009, “Embryology”. In: Bowler P. J., Pickstone J. V. (eds), The Cambridge History of Science, vol. 6: The Modern Biological and Earth Sciences, Cambridge: Cambridge University Press, 285-315.

Jacob F., 1973 [1970], The Logic of Life. A History of Heredity, trans. Spillmann B., New York: Pantheon.

Koselleck R., 1985, Futures past. On the Semantics of Historical Time, trans. Tribe K., Cambridge, MA: MIT Press.

Kussmaul A., 1859, Untersuchungen über das Seelenleben des neugeborenen Menschen, Leipzig: C.F. Winter'sche Verlagshandlung.

Legrand du Saulle H., 1884, "Influence des événements politiques sur les caractères du délire et anomalies physiques et intellectuelles que l'on observe chez les enfants conçus pendant le siège de Paris", Le Practicien, 7: 180-163.

Lenoir T., 1982, The Strategy of Life. Teleology and Mechanics in Nineteenth-Century German Biology, Dordrecht: D. Reidel.

Lepenies W., 1976, Das Ende der Naturgeschichte. Wandel kultureller

Selbstverständlichkeiten in den Wissenschaften des 18. und 19. Jahrhunderts, Munich: Hanser.

Lopéz-Beltrán C., 2004, “In the Cradle of Heredity; French Physicians and L'Hérédité Naturelle in the Early 19th Century", Journal of the History of Biology, 37: 39-72. Lopéz-Beltrán C., 2007, “The Medical Origins of Heredity”. In: Müller-Wille S., Rheinberger H.-J. (eds), Heredity Produced. At the Crossroads of Biology, Politics, and Culture, 1500-1870, Cambridge, MA: MIT Press, 105-132.

Maienschein J., 2003, Whose View of Life? Embryos, Cloning, and Stem Cells, Cambridge, MA: Harvard University Press. 
Mendelsohn J.A., 2001, "Medicine and the Making of Bodily Inequality in TwentiethCentury Europe”. In: Gaudillière J.-P., Löwy I. (eds), Heredity and Infection. The History of Disease Transmission, London: Routledge, 21-79.

Mocek R., 1998, Die werdende Form. Eine Geschichte der Kausalen Morphologie, Marburg: Basilisken-Presse.

Mucchielli L., 1998, “Aux origines de la psychologie universitaire en France (1870-1900): enjeux intellectuels, contexte politique, réseaux et stratégies d'alliance autour de la Revue philosophique de Théodule Ribot", Annals of Science. The History of Science and Technology, 55: 263-289.

Müller J., 1824, “Zur Physiologie des Foetus”, Zeitschrift für die Anthropologie, 2. Vierteljahresheft: 423-483.

Müller J., 1840, Handbuch der Physiologie des Menschen, vol. 2, Coblenz: Verlag von J. Hölscher.

Müller-Wille S., Rheinberger H.-J. (eds), 2007, Heredity Produced. At the Crossroads of Biology, Politics, and Culture, 1500-1870, Cambridge, MA: MIT Press 2007.

Nuño de la Rosa L., 2010, "Becoming Organisms: The Organisation of Development and the Development of Organisation”, History and Philosphy of the Life Sciences, 32: 289315.

Oppenheimer J.M., 1968, “Some Historical Relationships between Teratology and Experimental Embryology”, Bulletin of the History of Medicine, 42, no. 2: 145-159.

Ottavi D., 2001, De Darwin à Piaget. Pour une histoire de la psychologie de l'enfant, Paris: CNRS Edition.

Parnes O.S., 2007, “On the Shoulders of Generations: The New Epistemology of Heredity in the Nineteenth Century”. In: Müller-Wille S., Rheinberger H.-J. (eds), Heredity Produced. At the Crossroads of Biology, Politics, and Culture, 1500-1870, Cambridge, MA: MIT Press, 315-347. 
Parnes O.S., Vedder U., Willer S., 2008, Das Konzept der Generation. Eine Wissenschaftsund Kulturgeschichte, Frankfurt am Main: Suhrkamp.

Preyer W. T., 1880, Naturwissenschaftliche Thatsachen und Probleme. Populäre Vorträge, Jena: Gebrüder Paetel.

Preyer W. T., 1883, Specielle Physiologie des Embryo. Untersuchungen über die Lebenserscheinungen vor der Geburt, Leipzig: Th. Grieben's Verlag (L. Fernau). Preyer W.T., 1905 [1882], The Mind of the Child, Part I: The Senses and the Will, translated by H.W. Brown, New York: D. Appleton and Company.

Prochiantz A., 1990, Claude Bernard. La revolution physiologique, Paris: PUF.

Prochiantz A., 2012, Qu'est-ce que le vivant?, Paris: Seuil.

Rheinberger H.-J., 2001, Experimentalsysteme und epistemische Dinge. Eine Geschichte der Proteinsynthese im Reagenzglas, Göttingen: Wallstein.

Rheinberger H.-J., Müller-Wille S., 2009, Vererbung. Geschichte und Kultur eines biologischen Konzepts, Frankfurt am Main: Fischer.

Schafer, S., 2009, "History of the Physician as Scientist". In: Schafer S. (ed.), The Vanishing Physician-Scientist?, Ithaca: Cornell University Press, 17-38.

Temkin O., 1950, "German Concepts of Ontogeny and History around 1800", Bulletin of the History of Medicine, 24: 227-246.

Vignes H., 1924, "Pathologie anténatale et hérédité morbide, La pathologie germinale, la pathologie anténatale de la fécondation à la maturité foetale, Les échéances de la pathologie anténatale", Progrès médical, 1924, nos. 9, 10, 13, 15: 129-31, 142-46, 196-99, 231-33.

Wellmann J., 2010, Die Form des Werdens. Eine Kulturgeschichte der Embryologie, 17601830, Göttingen: Wallstein. 